\title{
POTENSI DAN PERAN PESANTREN SEBAGAI LEMBAGA PELAKSANA KEGIATAN REHABILITASI HUTAN DAN LAHAN (RHL)
}

\author{
(Potency and Role of the Moslem Boarding School as an Institution \\ to Execute for Land and Forest Rehabilitation Activity)
}

\author{
Oleh/By : \\ Dian Diniyati, Eva Fauziyah \& Budiman Achmad \\ Balai Penelitian Kehutanan Ciamis \\ Jl. Raya Ciamis Banjar Km 4 dsn Pamalayan Ciamis \\ Telp.081546815496_Alamat e-mail dian_diniyati@yahoo.com
}

\begin{abstract}
Pesantren as the Moslem boarding school is defined as a social community with high contribution in governing santri for their life surround which provides a direction and a guideline to societies. The board's component consist of : lodgings, mosque, santri, classical Islamic book and the kyai as a dominant factor. As the forest and land rehabilitation activities need mass people involved, the charismatic kyai and norms are two energy which can mobiliz people. The Moslem boarding school is usually located in villages surrounding the forest, so that it would be easier to gather and involve local people. That's why the Moslem boarding school is properly playing more actively role in any environmental conservation efforts, such as greening their own lands and surrounding including the privately owned forest which is able to increase their income. For that reason, the role and comparative advantages of the board need to be promoted especially in relation to the rehabilitation. The study was coducted in Lubur Al-wasilah (Garut district, Cibiuk subdistrict, Majasari village) and Cintawana Moeslem school boards (Tasikmalaya district, Tanjungjaya subdistrict, Cilolohan village) during May to December 2007. Data were collected by interviewing 2 kyais, 6 the board officers and 29 students supported by questionairy and then discriptively analyzed. The result showed that the boards have been actively involved in the forestry activities such as building the nursery and facilitating the network between farmers, privates and goverment sectors. The comparative advantages of the boards comprises of job networking, human resources, social, demography and economics aspecs.
\end{abstract}

Keywords: Moslem boarding school, santri, forest and land rehabilitation, norms, comparative advantages

\begin{abstract}
ABSTRAK
Pesantren merupakan suatu komunitas sosial yang cukup dominan dalam mengatur tata kehidupan masyarakatnya dalam menghadapi kehidupan sehingga dapat memberikan arahan dan pedoman. Komponen pesantren terdiri dari: pondok, mesjid, satri, kitab Islam klasik, dan faktor dominan adalah Kyai. Kyai yang kharismatik serta adanya norma merupakan suatu kekuatan yang menonjol di pesantren, yang dapat dimanfaatkan dalam kegiatan RHL. Apalagi kegiatan RHL diutamakan adalah massa yang banyak untuk melaksanakan gerakan rehabilitasi hutan dan lahan, salah satunya hutan rakyat. Lokasi pesantren umumnya berada di pedesaan sekitar hutan, sehingga dapat memberdayakan masyarakat sekitarnya. Hal tersebut menjadi dasar melibatkan pesantren agar berperan aktif dalam upaya pelestarian dan pemeliharaan lingkungan seperti menanami lahan yang dimilikinya untuk menghijaukan wilayah sekitarnya, sekaligus bisa memperoleh pendapatan dari kayunya. Maka perlu diuraikan peranan serta keunggulan komparatif yang dimiliki pesantren dalam kegiatan RHL. Kegiatan penelitian ini dilaksanakan di Pesantren Luhur Al-wasilah (Kabupaten Garut, Kecamatan Cibiuk Desa Majasari) serta Pesantren Cintawana (Kabupaten Tasikmalaya Kecamatan Tanjungjaya Desa Cilolohan) dilaksanakan bulan Mei Desember 2007. Unit Analisisnya adalah pondok
\end{abstract}


pesantren dengan responden Kyai (2 orang), pengurus pesantren (6 orang) dan santri sebanyak 29 orang. Data dikumpulkan dengan metode wawancara menggunakan kuisioner, selanjutnya dianalisis secara deskriptif. Hasil analisis menunjukan bahwa pesantren terlibat pada kegiatan kehutanan sebagai pelaksana pembuatan persemaian, dan fasilitator memediasi antara petani dengan pihak swasta dan pemerintah. Keunggulan komparatif yang dimiliki pesantren terbagi atas aspek jaringan kerja, sumber daya manusia, sosial, demografi dan ekonomi.

Kata kunci: Pesantren, santri, RHL, norma, keunggulan komparatif

\section{PENDAHULUAN}

Pesantren merupakan salah satu lembaga pendidikan yang unik yang menjadi ciri khas Indonesia, karena mempunyai norma dan peraturan tertentu yang menjadi ciri dari pesantren. Pesantren juga merupakan salah satu dari lembaga kemasyarakatan yang tumbuh karena masyarakat membutuhkan pendidikan. Lebih jauh Suyuti (2008) mengatakan bahwa pesantren memiliki komponen-komponen yang terdiri dari: kyai, santri, masjid, pondok dan kitab kuning.

Menurut Soekanto (2003) lembaga kemasyarakatan yang bertujuan memenuhi kebutuhan pokok manusia pada dasarnya mempunyai beberapa fungsi, yaitu:

1. Memberikan pedoman pada anggota masyarakat, bagaimana mereka harus bertingkah laku atau bersikap di dalam menghadapai masalah-masalah dalam masyarakat, terutama yang menyangkut kebutuhan-kebutuhan.

2. Menjaga keutuhan masyarakat.

3. Memberikan pegangan kepada masyarakat untuk mengadakan sistem pengendalian sosial (social control), yaitu suatu sistem pengawasan masyarakat terhadap tingkah laku anggota-anggotanya.

Dengan adanya fungsi tersebut memperjelas pesantren mempunyai peranan yang sangat penting di masyarakat, karena secara langsung maupun tidak langsung dapat memberi pedoman kepada para anggotanya untuk bersikap dan bertingkah laku kepada pencipta semesta alam ini, kepada sesama manusia serta kepada alam sekitarnya. Kegiatan pesantren lebih banyak pada hal-hal yang terkait dengan keagamaan, namun seiring dengan perubahan waktu dan adanya perubahan kebutuhan, banyak kyai yang berasal dari pesantren, mulai memperhatikan kondisi alam dan mulai terjun pada kegiatan rehabilitasi hutan dan lahan. Apabila para kyai sudah mulai tertarik kepada kegiatan RHL, bukan tidak mungkin para santrinya akan ikut terlibat dalam kegiatan yang sama, karena ada norma kebiasaan harus menghormati dan menghargai para kyai.

Norma yang berlaku di pesantren sudah merupakan kebiasaan (folkways), sehingga sudah mempunyai kekuatan mengikat yang besar antara santri dengan kyai-nya. Apabila perbuatan menghormati dan menghargai para kyai tidak dilakukan oleh santri, maka dianggap sebagai penyimpangan terhadap norma yang berlaku tersebut. Selain itu, dengan adanya kharisma para kyai akan memudahkan dalam menggerakkan massa santri dalam kegiatan RHL.

Saat ini jumlah pondok pesantren di Indonesia cukup banyak yakni sekitar 11.312 (jumlah santri sebesar 2.737.805 jiwa) dimana 78\% pesantren berada di pedesaan. Sedangkan jumlah pesantren di Jawa Barat pada tahun 2005 sebanyak 4.388 unit yang terdiri dari 1.311 pesantren berlokasi di daerah pegunungan, 1.085 di daerah pertanian, 87 di sekitar pantai, dan 114 berada di tepi sungai (Departemen Agama, 2001 dalam Hermawan, 2007). 
Uraian di atas menunjukkan bahwa pesantren memiliki modal yang dapat dijadikan sebagai kekuatan untuk dapat terlibat dalam kegiatan RHL. Tulisan ini mencoba menguraikan peranan serta keunggulan komparatif yang dimiliki oleh pesantren dalam kegiatan RHL. Keunggulan komparatif adalah suatu keunggulan yang dimiliki oleh suatu organisasi untuk dapat membandingkannya dengan yang lainnya (Anonim, 2010). Potensi pesantren diantaranya adalah memiliki sumber daya manusia (SDM) yang handal dari segi kuantitas dan kualitas dan umumnya berada di level grass root (tingkat pedesaan) menyatu dengan lingkungan pedesaan, jaringan kerja (jumlah pontren yang banyak), dan memiliki sistem tata nilai dan norma yang baik.

\section{METODE PENELITIAN}

\section{A. Lokasi dan Waktu}

Kegiatan penelitian ini dilakukan di Desa Majasari Kecamatan Cibiuk Kabupaten Garut, serta Desa Cilolohan Kecamatan Tanjungjaya Kabupaten Tasikmalaya. Kegiatan Penelitian ini dilakukan bulan Mei Desember 2007.

\section{B. Pengambilan sampel}

Sampel penelitian ini terbagi atas dua yaitu:

1. Pesantren, dipilih secara sengaja (purposive sampling) yaitu pesantren Luhur Al-wasilah (Kabupaten Garut) dan Pesantren Cintawana (Kabupaten Tasikmalaya), didasarkan pertimbangan bahwa kedua pesantren tersebut telah terlibat kegiatan RHL dan mengembangkan penghijauan lingkungan.

2. Responden penelitian adalah kyai masing-masing satu orang dan pengurus pesantren sebanyak 6 orang, serta mustame (santri) yang tergabung dalam kelompok tani dipilih secara sengaja sebanyak 13 orang Desa Majasari dan 16 orang Desa Cilolohan. Populasi dalam penelitian ini merupakan keseluruhan anggota kelompok tani yang terlibat dalam pengembangan penghijauan lingkungan bersama pesantren.

\section{Pengumpulan Data}

Data yang dikumpulkan terdiri dari data primer dan sekunder:

1. Data primer diperoleh dengan cara wawancara menggunakan kuisioner yang telah dipersiapkan terlebih dahulu, selain itu juga dilakukan diskusi dengan menggunakan interview guide.

2. Data sekunder diperoleh dengan cara penelusuran data dan informasi yang berasal dari laporan-laporan instansi-instansi terkait yang berhubungan dengan kegiatan penelitian ini.

\section{Analisis Data}

Untuk memperoleh luaran mengenai peranan dan keunggulan komparatif yang dimiliki pesantren dalam melaksanakan kegiatan RHL dan penghijauan lingkungan, maka data yang diperoleh selanjutnya dianalisis secara kualitatif (deskriptif). Teknik kualitatif yakni mengolah dan menganalisis data-data yang terkumpul menjadi data yang sistematik, teratur, terstruktur dan mempunyai makna (Sarwono, 2006). 


\section{HASIL DAN PEMBAHASAN}

\section{A. PANDANGAN PESANTREN TENTANG PENGHIJAUAN LINGKUNGAN (RHL)}

\section{Pesantren Luhur Al-Wasilah}

Pesantren Luhur Al-Wasilah di Kabupaten Garut dipimpin oleh Bapak Kyai Thonthowi Djauhari Musaddad merupakan Rois Syuriah NU Cabang Garut periode 19992004 dan periode 2004-2009. Bapak Kyai sangat memperhatikan masalah lingkungan sehingga melakukan kegiatan cinta lingkungan, melibatkan masyarakat yang ikut pengajian di Pesantren luhur Al-Wasilah, juga memanfaatkan NU sebagai kendaraan untuk melakukan penyuluhan tentang lingkungan kepada warga NU khususnya dan masyarakat pada umumnya.

Kegiatan yang diusung pesantren adalah mendekatkan permasalahan atau meletakan kegiatan langsung pada akarnya yaitu desa. Sesuai UU No. 32 tahun 2004 tentang Pemerintahan Daerah dimana peranan masyarakat lebih dominan keterlibatannya dalam proses pembangunan. Selain itu jika ditinjau dari perubahan kebijakan politik yaitu mengenai desentralisasi pengelolaan sumber daya alam hutan (SDAH) (UU No. 22/99 dan UU No. 41 tentang kehutanan) dan perimbangan keuangan pusat dan daerah (UU No. 25/99), pelimpahan kewenangan sebaiknya diberikan seluas-luasnya kepada lembaga pemerintah dan lembaga rakyat yang paling dekat dengan SDAH yaitu tingkat kampung/ desa yang merupakan makna devolusi sebagai syarat berjalannya lembaga demokrasi. (Awang, 2007 dan Musaddad, 2007). Pesantren (Kyai Thonthowi Djauhari Musaddad) yang melakukan program pembangunan pedesaan mandiri diarahkan bagi penguatan pelaksanaan otonomi desa, yang diupayakan pada optimalisasi partisipasi masyarakat desa, sikap kemandirian individu yang berorientasi pada kemandirian masyarakat desa, kesadaran masyarakat terhadap sistem sosial sebagai aspek yang saling berkaitan, pola pikir sadar pada proses, peluang serta tantangan dalam setiap aspek pembangunan.

Kemandirian diterjemahkan sebagai kesanggupan suatu desa untuk memberdayakan setiap potensi sumber daya manusia (SDM) dan sumber daya alam (SDA) yang kesemuanya dikelola menjadi kekuatan sistem di desa itu sendiri (Musadad, 2007). Kemandirian tercipta dengan cara memberdayakan masyarakat itu sendiri. Pada dasarnya masyarakat siap untuk melaksanakan pelestarian lingkungan, dengan syarat:

1. kahartos (dapat dimengerti)

2. baktos (karya nyata yaitu aksi dengan program yang real/nyata)

3. karaos (ada kontribusinya bagi kehidupan masyarakat)

4. artos dan raos (ada kontribusi terhadap ekonomi dan kesejahteraan masyarakat).

Korban akibat lingkungan yang rusak pada umumnya adalah masyarakat miskin yang tinggal di pedesaan. Salah satu cara untuk memperbaikinya adalah dengan melakukan pendekatan agama. Masalah lingkungan merupakan masalah agama, karena kerusakan lingkungan akibat degradasi moral manusia. Apabila manusia beriman maka moralnya dapat dikontrol oleh dirinya sendiri sebaliknya apabila tidak bermoral maka agamalah yang harus meluruskannya. Agama merupakan tuntunan hidup baik di dunia maupun di akherat nantinya.

Kerusakan lingkungan selain diakibatkan oleh moral yang terdegradasi, agama juga menyuruh manusia untuk melestarikan lingkungan, sehingga Pak Kyai berijtihad bahwa 
pelestarian lingkungan hukumnya wajib ain bagi setiap individu dilingkungannya masingmasing dan wajib kipayah bagi semua masyarakat. Lingkungan seperti hutan harus dijaga kelestariannya, karena hutan merupakan tempat yang dibutuhkan oleh semua makhluk hidup baik secara langsung maupun tidak langsung. Bagi umat Islam apabila mau melakukan kewajiban sholat maka tubuh harus bersih dan suci, dan bersuci harus menggunakan air bersih, sedangkan air dapat tersedia apabila tempat dan sumber air terpelihara dengan baik, sehingga air bersihpun akan tetap tersedia. Sumber air tersedia apabila hutannya lestari, untuk itu diwajibkan untuk memelihara hutan.

Dalam norma agama terdapat banyak hal untuk memotifasi manusia agar melestarikan lingkungan karena hal ini merupakan bagian dari ibadah. Maka Pak Kyai sebagai pemuka agama, ormas, pimpinan pontren dan pribadi, mempunyai kewajiban religi dalam melestarikan lingkungan. Diharapkan norma agama dapat menembus hati manusia untuk melaksanakan penanaman pohon dengan dilandasi ibadah, sehingga menanam pohon dilakukan secara sukarela tanpa ada paksaan dan embel-embel lainnya (misal adanya dorongan proyek). Sosialisasi norma agama dilakukan lewat buku dan lagu-lagu agama yang berhubungan dengan kelestarian alam dan kegiatan ini sudah disosialisasikan melalui kegiatan salawatan di masjid yang ada di desa (kampung).

Melestarikan lingkungan dalam Agama dikatagorikan sebagai Shodakoh Jariyah, artinya walaupun manusia sudah meninggal tetapi pahalanya akan terus mengalir selama tanaman itu tumbuh, karena tanaman sangat diperlukan oleh semua makhluk hidup baik secara langsung maupun tidak langsung.

Bentuk dari kegiatan pelestarian lingkungan dan RHL yaitu kegiatan persemaian. Kegiatan ini dilaksanakan oleh mustame (masyarakat yang ikut pengajian di pesantren) bekerjasama dengan pesantren Luhur Al-Wasilah. Kegiatan ini dapat dikatakan berhasil. Indikator keberhasilannya yaitu ekonomi masyarakat pelaksana program mengalami peningkatan seperti dapat menyekolahan anak, membuat rumah, bahkan membeli lahan. Keberhasilan lain dari program ini adalah berhasil membina masyarakat sehingga dapat beralih ke persemaian setelah mendengar ceramah dari Pak Kyai tentang sebuah hadist bahwa wanita pelacur yang memberikan air minum terhadap anak anjing yang kehausan, kemudian dosanya diampuni, dan dosa yang sangat besar diampuni dengan hal yang sepele apabila dilakukan dengan iklas. Dengan demikian apabila seseorang menanam pohon dengan ikhlas karena Allah tanpa pamrih maka Insya Allah dosanya akan diampuni, karena sebuah pohon sangat berguna sekali bagi kehidupan untuk semua makluk hidup.

\section{Pesantren Cintawana}

Yayasan pesantren Cintawana terletak di Desa Cikunten, Kecamatan Singaparna, Kabupaten Tasikmalaya, Jawa Barat. Pesantren ini didirikan pada tahun 1917 oleh KH. Mohammad Toha (Alm) dan sekarang dipimpin oleh generasi ke 3 yaitu Kyai Asep Sujai Farid.

Organisasi dan program pengajaran di Pesantren Cintawana terdiri dari Badan Permusyawaratan Pesantren yang bertujuan untuk meningkatkan kualitas pendidikan pesantren, bidang pendidikan santri, bidang pendidikan sekolah, bidang keterampilan/ ekonomi yang meliputi koperasi pesantren Cintawana (KOPCI) dan BMT (Baitul Mal Watamwil), komputer, dan kegiatan lain dibidang pertanian, kehutanan, perikanan, peternakan, dan perkebunan. Selain itu terdapat pula pendidikan untuk masyarakat/majelis taklim berupa pengajian yang dilaksanakan rutin maupun insidentil. 
Pensantren Cintawana memiliki perhatian terhadap hutan sejak milad (ulang tahun) ke 90. Keterlibatan pesantren dalam kegiatan kehutanan disebabkan oleh banyaknya permasalahan yang dihadapi oleh masyarakat, setelah mereka bekerjasama dengan perusahaan atau pemerintah sehingga memerlukan pendamping. Pelibatan santri dilakukan dengan memilih santri-santri tertentu yang mempunyai minat saja terutama santri dewasa yang mempunyai potensi dan kemauan untuk melakukan survei, pemetaan, dan lainnya.

Santri dewasa tersebut berada di graas root sehingga memudahkan dalam pembinaan lingkungan (hutan rakyat) kepada masyarakat. Maka strategi untuk menarik minat masyarakat supaya mau aktif dalam program lingkungan yaitu dengan memperkenalkan pasar dari hasil hutan rakyat sengon. Caranya dengan membawa masyarakat untuk datang ke PT. BKL (Bina Kayu Lestari), tujuannya supaya masyarakat memperoleh dan melihat langsung manfaat yang akan diperoleh dari kerjasama, selai itu salah satu kelemahan masyarakat dalam kerjasama adalah rendahnya tingkat pengetahuan manajemen, modal serta akses informasi. Dari sinilah awal mulanya kerjasama antara pesantren, masyarakat dan PT BKL.

Kerjasama dengan PT BKL yaitu perusahaan kayu Tasikmalaya yang mengolah bahan baku kayu sengon, dilakukan pesantren dengan dasar kepentingan yang sama terhadap hutan rakyat, sehingga dibentuk kemitraan antara petani dengan BKL yang difasilitasi oleh pesantren. Hutan rakyat kemitraan dengan BKL sudah berjalan selama 5 tahun pada lahan seluas 35 ha (rencana sekitar 500 ha) yang dilakukan pada lahan milik desa/pengangonan di Kecamatan Tanjung Jaya pada bulan Februari tahun 2007. Kerjasama lainnya adalah pesantren dengan Balai Pengelolaan Daerah Aliran Sungai (BPDAS), yang melibatkan masyarakat dan alumni pesantren serta pemerintah daerah setempat. Model kerjasamanya yaitu mendorong masyarakat untuk menanam kayu terutama sengon, dimana petani pada awalnya hanya menanam singkong. Dalam kerjasama dengan swasta maupun pihak pemerintah, kontribusi dan peran pesantren sangat beragam. Prioritas pesantren dalam kerjasama ini adalah pencarian pasar. Perjanjian dibuat antara petani, pesantren dan pemerintah daerah, dimana pesantren berperan sebagai fasilitator/penengah agar semua pihak tidak ada yang merasa dirugikan. Peran lain adalah mencarikan dana lain untuk disalurkan pada petani dan juga melakukan fungsi kontrol terhadap kegiatan selama 3 kali dalam satu bulan.

Untuk melaksanakan program tersebut maka dibentuk kelompok tani oleh pesantren, aparat desa dan pemerintah pusat, sistem pengelompokkan petani berdasarkan letak lahan. Jumlah anggota kelompok tani 300 orang, terbagi dalam 35 ha lahan, yang tersebar di Desa Cilolohan, Suka Senang, dan Cikesal, pemilihan desa tersebut berdasarkan kesiapan kelompok dan kesiapan lahan yaitu ada lahan kritis. Disetiap desa terdapat satu orang koordinator dan ada alumni pesantren yang membantu kegiatan ini. Hasil sampingan dari program tersebut adalah peningkatan kemampuan petani dalam pemanfaatan lahan sehingga diperoleh hasil sampingan seperti jagung, singkong, ubi, kacang, dan sebagainya.

Hutan rakyat memiliki nilai ekonomi yang cukup menjanjikan jika petani memenuhi kesepakatan mengenai umur panen kayu. Untuk kepentingan konservasi, hutan rakyat mempunyai manfaat untuk menjaga ketersediaan air.

Kendala yang selama ini dihadapi oleh pesatren dalam menjalin kerjasama adalah kesulitan mencari instansi/perusahaan/mitra yang bisa diajak bekerjasama, berpihak kepada masyarakat, dan lebih mendahulukan kepentingan sosial. Dalam dakwah untuk santri maupun petani ditanamkan pemahaman bahwa kegiatan menanam merupakan ibadah, sehingga pesantren meluncurkan program santri menanam dan memberi dakwah tentang lingkungan kepada masyarakat dan para santrinya. 
Kegiatan lainnya yang berhubungan dengan kehutanan adalah pelatihan persemaian, dengan narasumber dari BKL dan Dinas Kehutanan Kabupaten Tasikmalaya. Pesantren pernah membuat persemaian sebanyak 180.000 bibit. Bibit yang pernah disemaikan berasal dari Jawa Tengah, namun mati setelah sampai di lokasi persemaian. Pada saat ini persemaian untuk jenis sengon akan dibuat di lokasi yang berdekatan dengan lokasi penananaman, untuk meningkatkan kualitas bibit saat siap tanam.

\section{B. PERANAN PESANTREN DALAM KEGIATAN REHABILITASI HUTAN DAN LAHAN}

Kerusakan lingkungan saat ini sudah menjadi isu sangat penting dan membutuhkan penanganan serius. Salah satu upaya yang dilakukan oleh pemerintah khususnya Departemen Kehutanan adalah dengan menggalakkan pembangunan hutan/penghijauan lingkungan diantaranya melalui program Gerhan atau rehabilitasi hutan dan lahan (RHL) baik di lahanlahan kritis maupun di lahan-lahan masyarakat yang belum optimal pemanfaatannya.

Gerhan yang dilaksanakan sejak tahun 2003 merupakan gerakan moral menuju percepatan pemulihan keberadaan dan fungsi hutan untuk meningkatkan kesejahteraan masyarakat. RHL sendiri bertujuan untuk memulihkan, mempertahankan dan meningkatkan fungsi hutan dan lahan sehingga daya dukung, produktivitas dan peranannya dalam mendukung sistem penyangga kehidupan tetap terjaga (Anonim, 2007). Gerhan merupakan salah satu upaya strategis pembangunan yang langsung menyentuh masyarakat (massa) yang memerlukan keterlibatan masyarakat dalam pelaksanaannya.

Selain program Gerhan masih banyak program-program lainnya yang dicanangkan pemerintah. Dalam pelaksanaannya Departemen Kehutanan tidak bergerak sendiri tetapi melibatkan berbagai elemen masyarakat, lembaga formal maupun informal. Salah satu lembaga informal yang dilibatkan adalah Pesantren.

Pesantren merupakan lembaga yang potensial dalam menyukseskan gerakan menanam pohon, melalui pelibatan para santri sebagai pengorganisir masyarakat untuk mengembangkan pengetahuan dan kemampuan ekonomi masyarakat dalam usaha pertanian yang ramah lingkungan, menggunakan sistem nilai dan pengetahuan tradisional masyarakat, dan sebagainya. Pesantren juga dinilai memiliki peran strategis dalam memberdayakan masyarakat sekitar hutan, termasuk menggerakkan masyarakat dalam menanggulangi lahan kritis, karena pesantren rata-rata berada di pedesaan, dengan kyai yang memiliki karisma baik di mata masyarakat (Anonim, 2005).

Kerjasama dengan Pesantren atau lembaga/ormas Islam telah dilakukan pada tahun 1999, dimana Departemen Kehutanan dan Perkebunan (Dephutbun) melakukan kerjasama dengan MUI (Majelis Ulama Indonesia) untuk meningkatkan efektivitas dan efisiensi mutu sumberdaya manusia, dan kemampuan institusi dan fungsi kelembagaan Dephutbun dan MUI khususnya dalam mendukung pembangunan di bidang kehutanan dengan jangka waktu 3 tahun (Nasution, 1999). Pada saat ini, program rehabilitasi dan penghijauan (Gerhan) melalui program "Santri Menanam, Kyai Memanen" juga dilakukan Departemen Kehutanan bekerja sama dengan pesantren maupun lembaga keagamaan lainnya.

Sejauh ini keterlibatan pesantren dalam pembangunan kehutanan khususnya kegiatan RHL dan hutan rakyat masih terbatas pada kegiatan pembuatan persemaian, pembagian dan penanaman pohon, atau sebagai mediator/fasilitator antara masyarakat dengan pemerintah atau swasta. Pesantren Cintawana menjadi mediator dan fasilitator dalam program hutan 
rakyat antara mustame dan BKL, dan pesantren Luhur Al-wasilah telah melakukan pembibitan. Namun keterlibatan dalam kegiatan pengawasan, penyuluhan, kelembagaan, dan pemasaran masih belum terlihat jelas. Hal ini disebabkan oleh faktor internal pesantren itu sendiri seperti segi skill dan pengetahuan tentang kehutanan yang masih rendah maupun faktor eksternal seperti kondisi politik/lingkungan.

Sebenarnya saat ini beberapa pesantren sudah mulai memasukan materi lingkungan atau masalah kehutanan dalam kurikulum pengajarannya atau menjadi salah satu isi kajian dalam pengajian dengan mustamenya. Ditekankan bahwa masalah lingkungan merupakan masalah agama dengan beberapa dasar diantaranya : 1) kerusakan hutan dan lingkungan yang terjadi selama ini merupakan ulah manusia yang tidak bermoral (moral adalah masalah agama), 2) agama memerintahkan bahwa melestarikan lingkungan hukumnya adalah wajib, dan 3) banyak norma agama yang memotivasi untuk melestarikan lingkungan. Namun diakui bahwa hal ini belum dilakukan sepenuhnya dan belum dapat diimplementasikan di lapangan secara utuh.

Peran pesantren sangat potensial untuk mendukung suksesnya program RHL dan penghijauan lingkungan, melalui kampanye tentang pentingnya menjaga lingkungan dilakukan sampai tingkat desa dengan metode ceramah, sehingga pada setiap pengajian dapat disisipkan materi mengenai lingkungan. Forum pengajian biasanya sudah melembaga, sehingga bisa menjadi salah satu wadah yang dapat dimanfaatkan untuk kegiatan penyuluhan tentang pentingnya lingkungan, maupun media sosialisasi program baik di bidang kehutanan atau lainnya yang berasal dari pemerintah, LSM, dan sebagainya.

Hal ini diperkuat dengan faktor dominan dari para kyai, seperti diciptakan sholawat lingkungan (pesantren Luhur Al-wasilah), yang sering dikumandangkan pada saat pengajian ataupun sebelum adzan. Metode ceramah digunakan dengan harapan dapat merubah pola pikir, bahwa pentingnya menjaga lingkungan merupakan bagian dari agama (ibadah), dan diimplementasikan melalui penanaman pohon/kayu. Upaya merubah pola pikir tidak hanya dilakukan pesantren melalui ceramah saja, tetapi juga dengan tindakan nyata melalui pembagian bibit pohon/kayu dan polybag kepada masyarakat secara gratis.

Seperti disampaikan oleh Diniyati, dkk (2008) bahwa para mustame sudah mengetahui dan menyadari bahwa dengan menanami lahan-lahan yang terlantar/gersang dengan tanaman kehutanan/buah-buahan, maka akan menghasilkan keuntungan dari aspek ekonomi dan ekologi. Aspek ekonomi memberikan keuntungan seperti menghasilkan kayu yang akan dipergunakan sendiri ataupun untuk dijual, tabungan dan menambah pendapatan. Aspek ekologi yang sangat dirasakan yaitu wilayah tersebut menjadi hijau dengan tanaman sehingga dapat menghasilkan air. Air ini bermanfaat untuk keberhasilan (membersihkan diri) diantaranya untuk berwudu. Wudu ini diperlukan untuk membersihkan diri dari kotoran supaya dapat menjalankan ibadah sholat. Sholat merupakan perintah Allah SWT yang harus ditaati oleh umat muslim. 
Tabel 1. Nilai Konservasi Hutan Rakyat Menurut Mustame

Table 1. Conservation value of Privately owned forests by mustame (respondent)

\begin{tabular}{|c|c|c|c|c|}
\hline \multirow{2}{*}{$\begin{array}{c}\text { Desa } \\
(\text { Village })\end{array}$} & \multicolumn{4}{|c|}{ Manfaat Hutan Rakyat } \\
\hline & Ekonomi (Economy) & $\begin{array}{c}\Sigma \\
\text { Responden } \\
\text { (Respondent) }\end{array}$ & Ekologi (Ecology) & $\begin{array}{c}\Sigma \\
\text { Responden } \\
\text { (Respondent) }\end{array}$ \\
\hline Cilolohan & $\begin{array}{ll}\text { - } & \text { Nilai ekonomi, finansial } \\
\text { - } & \text { Peningkatan modal } \\
\text { - } & \text { Tidak langsung } \\
& \text { menghasilkan } \\
\text { - } & \text { Hasilnya tidak sesuai } \\
& \text { yang diharapkan } \\
\text { - } & \text { Pasaran tinggi }\end{array}$ & $\begin{array}{l}9 \\
1 \\
1 \\
3 \\
2\end{array}$ & $\begin{array}{l}\text { - Menjaga longsor } \\
\text { dan erosi } \\
\text { - Menyediakan air } \\
\text { dan udara bersih } \\
\text { - Menghijaukan } \\
\text { kembali hutan } \\
\text { - Tidak tau }\end{array}$ & $\begin{array}{l}10 \\
1 \\
3 \\
2\end{array}$ \\
\hline & Jumlah & 16 & Jumlah & 16 \\
\hline Majasari & $\begin{array}{ll}\text { - } & \text { Harga pasar bagus } \\
\text { - } & \text { Menambah } \\
& \text { pendapatan } \\
\text { - } & \text { Dikelola baik hasilnya } \\
\text { banyak } \\
\text { - } \text { Tabungan masa depan } \\
\text { - Dipergunakan untuk } \\
\text { kayu }\end{array}$ & $\begin{array}{l}5 \\
5 \\
1 \\
1 \\
1\end{array}$ & $\begin{array}{l}\text { - Menjaga longsor } \\
\text { - Menjaga } \\
\text { persediaan air } \\
\text { - Mencegah banjir } \\
\text { - Tidak ada }\end{array}$ & $\begin{array}{l}5 \\
5 \\
1 \\
2\end{array}$ \\
\hline & Jumlah & 13 & Jumlah & 13 \\
\hline
\end{tabular}

Sumber/ Source: Diniyati, dkk. (2008)/ Diniyai, et al. (2008)

\section{KEUNGGULAN KOMPARATIF PESANTREN}

Pesantren sebagai lembaga pendidikan Islam pertama dan khas pribumi Indonesia mempunyai keunikan atau kekhasan, tidak saja karena keberadaannya yang sudah sangat lama, tetapi juga karena kultur, metode dan jaringan yang diterapkan oleh lembaga tersebut. Pesantren juga memiliki basis sosial yang jelas, karena keberadaannya menyatu dengan masyarakat.

Pesantren merupakan lembaga yang memiliki keunggulan yang tidak dimiliki oleh lembaga lain atau lebih tepat disebut sebagai keunggulan komparatif. Sudaryanto dan Simatupang (1993) dalam Saptana (2008) menyatakan bahwa konsep keunggulan komparatif merupakan ukuran daya saing (keunggulan) potensial dalam artian daya saing yang akan dicapai apabila perekonomian tidak mengalami distorsi sama sekali. Konsep keunggulan komparatif ini lebih pada komoditas/produk, dimana komoditas yang memiliki keunggulan komparatif dikatakan juga memiliki efisiensi secara ekonomi.

Sebagai sebuah lembaga, pesantren memiliki keunggulan komparatif yaitu merupakan salah satu modal sosial (social capital) yang menjadikan pesantren layak sebagai lembaga pengembang hutan rakyat dibandingkan dengan lembaga lainnya. Akan tetapi masih harus diperkuat dari sisi keahlian manajerial, administrasi dan sisi bisnis. Beberapa keunggulan yang dimiliki pesantren, diantaranya seperti diperlihatkan pada Tabel 2. 
Tabel 2. Keunggulan Komparatif Pesantren

Table 2. Comparative advantages of the muslim school board

\begin{tabular}{|c|l|l|}
\hline No. & Aspek (Aspect) & Keunggulan Pesantrem (Advantages of the moslem school) \\
\hline 1. & Jaringan kerja & $\begin{array}{l}\text { - Terletak di desa dan berhubungan langsung dengan } \\
\text { masyarakat (grass root) } \\
\text { - Jumlah lembaga pesantren yang banyak }\end{array}$ \\
\hline 2. & Aspek Demografi & - Massa organisasi yang jelas \\
\hline 3. & Sumber Daya Manusia & $\begin{array}{l}\text { - Pemimpin (Kyai) yang karismatik/ Strong leadership } \\
\text { - Santri dan mustame berjumlah banyak }\end{array}$ \\
\hline 4. & Sosial & $\begin{array}{l}\text { - Sifat gotong royong dan kekeluarga an tinggi } \\
\text { - Manajemen massa yang baik }\end{array}$ \\
\hline 5. & Ekonomi & - Jumlah tenaga kerja yang banyak \\
\hline
\end{tabular}

Sumber/ Source: Analisis data primer, 2007/ Primary data analysis, 2007. berikut:

Berdasarkan Tabel 2 dapat diuraikan keunggulan komparatif pesantren sebagai

\section{1) Aspek Jaringan Kerja}

\section{- Jumlah organisasi pesantren banyak}

Saat ini jumlah pondok pesantren (pontren) di Indonesia sekitar 11.312 unit dengan jumlah santri 2.737.805 jiwa. Jumlah Pontren di Jawa Barat pada tahun 2005 sebanyak 4.388 unit yang terdiri dari 1.311 Pontren berlokasi di daerah pegunungan, 1.085 di daerah pertanian, 87 di sekitar pantai, dan 114 berada di tepi sungai (Departemen Agama, 2001 dalam Hermawan, 2007). Sebagai sebuah komunitas pesantren dapat berperan sebagai penggerak peningkatan kesejahteraan masyarakat, mengingat pesantren merupakan kekuatan sosial yang jumlahnya cukup besar.

Banyaknya pesantren akan menciptakan jaringan kerja yang baik, karena pesantren yang ada di pedesaan dapat dijadikan agen pengembangan hutan rakyat (penghijauan), sehingga dengan banyaknya agen maka pengembangan usaha hutan rakyat (penghijauan) akan lebih mudah dan murah.

\section{- Letak pesantren di pedesaaan}

Sekitar 78\% Pontren berada di pedesaan. Hal ini terjadi karena santri yang sudah lulus dari pesantren akan mengamalkan ilmunya dengan mendirikan pesantren di daerah asalnya, terutama para santri lulusan pesantren Cintawana dan pesantren Luhur Al-Wasilah.

Pesantren diharapkan turut memberi investasi sosial bagi masyarakat dan salah satu cara yang membuat pesantren menjadi hidup, adalah dengan membawa persoalan-persoalan nyata di masyarakat ke dalam dunia pesantren (Maarif, 2007). Dengan jumlah pesantren yang banyak dan tersebar di seluruh penjuru wilayah Indonesia, pesantren dapat menjadi sumber kekuatan dalam mengembangkan program penghijauan, karena tidak semua lembaga sosial memiliki jaringan sosial seluas pesantren.

\section{2) Aspek Demografi}

Keberadaan pesantren di Indonesia sudah cukup lama, sehingga lembaga ini memiliki massa yang pasti dengan jumlah yang banyak. Program, visi dan misi pesantren sudah jelas 
dan pasti, sehingga organisasi ini dari waktu ke waktu tidak pernah kekurangan massa, bahkan semakin bertambah. Ini merupakan keunggulan pesantren lainnya yang tidak dimiliki oleh lembaga sosial lain.

Massa yang banyak merupakan modal tenaga kerja yang dapat dimanfaatkan untuk melaksanakan kegiatan rehabilitasi hutan dan lahan. Adanya Norma menghormati Kyai sebagai guru di pesantren, akan lebih melancarkan kegiatan RHL karena para santri akan dengan iklas melakukan kegiatan RHL.

\section{3) Aspek Sumber Daya Manusia}

\section{- Pesantren mempunyai pimpinan/kyai yang kharismatik}

Kepemimpinan kyai dalam sebuah pesantren adalah penting, karena sangat berpengaruh terhadap kemampuan pesantren dan santrinya itu sendiri untuk terus maju dan berkembang. Jones (1991) menyatakan bahwa salah satu peranan pesantren adalah menjaga kestabilan masyarakat dengan membangun dan menjaga keseimbangan antara kaum-kaum yang berbeda status, khususnya antara golongan atas (elit) dan petani. Pesantren diyakini mempunyai peluang yang sangat besar dalam pengelolaan hutan. Hal ini disebabkan karena pesantren rata-rata berada di pedesaan dengan Kyai yang memiliki kharisma baik di mata masyarakat sehingga pesantren mempunyai pengaruh yang cukup kuat dalam memberdayakan masyarakat (Benda, 1958 dalam O'Hanlon, 2006; Qamarudin, 2005).

Dari hasil wawancara dengan salah satu pimpinan pesantren, diakui bahwa kepemimpinan mereka di pesantren sangat berpengaruh dan menentukan langkah dari pesantren yang dipimpinnya. Kharisma dari kyai memudahkan pelibatan santri atau mustamenya dalam kegiatan yang diprogramkan oleh pesantren, meskipun tidak ada imbalan/keuntungan secara langsung.

\section{- Massa (santri dan pengikut pesantren) yang banyak}

Salah satu komponen masyarakat yang diharapkan bisa berperan aktif dalam upaya konservasi alam dan lingkungan adalah pesantren. Menurut data Education Management and Information System (EMIS) Departemen Agama RI, tahun 2001 di seluruh Indonesia terdapat 11.312 pesantren dengan jumlah santri sebesar 2.737.805 jiwa. Dengan fakta seperti itu, pesantren merupakan salah satu komponen strategis bangsa yang bisa berperan efektif dalam upaya pelestarian dan pemeliharaan lingkungan.

\section{4) Aspek Ekonomi}

\section{- Tenaga kerja tersedia dalam jumlah yang banyak}

Seperti diuraikan pada pendahuluan bahwa saat ini jumlah pondok pesantren di Indonesia cukup banyak yakni sekitar 11.312 (jumlah santri sebesar 2.737.805 jiwa) (Departemen Agama, 2001 dalam Hermawan, 2007). Banyaknya santri dapat dijadikan sebagai modal tenaga kerja yang tersedia dalam jumlah banyak. Santri-santri yang bersedia bekerja dengan iklas dan tidak mengharapkan imbalan dapat digunakan dalam pengembangan usaha penghijauan (hutan rakyat).

Hubungan antara santri alumni pesantren dengan pesantrennya biasanya masih terjalin dengan baik, sehingga santri alumni dapat berperan sebagai perpanjangan tangan pesantren dalam menyukseskan program RHL yang dilakukan melalui pengajian/ceramah di tempat santri alumni menetap. Metode ini dapat dimasukkan sebagai salah satu program dari 
kegiatan pesantren dan hal ini dimungkinkan karena sistem pengajaran di pesantren terus berubah dan berkembang, dimana pendidikan ketrampilan kini diaplikasikan di pesantren.

\section{5) Aspek Sosial}

\section{- Sifat gotong royong dan kekeluargaan tinggi}

Pesantren memiliki basis sosial yang jelas, karena keberadaannya menyatu dengan masyarakat. Sifat gotong royong dan kekeluargaan umumnya masih melekat pada masyarakat pedesaan termasuk masyarakat yang basisnya pesantren. Terlebih lagi pesantren dengan mustamenya memiliki rutinitas pengajian yang secara langsung maupun tidak, dapat memperkokoh rasa kekeluargaan dan gotong rotong diantara sesama anggota pengajian tersebut.

Sifat ini merupakan kekuatan dan keunggulan yang tidak dimiliki oleh lembaga lain. Dengan rasa kekeluargaan yang tinggi dan sifat gotong royong maka kegiatan dapat terlaksana tanpa mengandalkan ketersediaan dana. Dana atau uang yang merupakan modal finansial yang penting, namun apabila hanya mengandalkan hal itu maka keberhasilan program akan sangat rendah. Modal sosial yang saat ini sudah banyak dikembangkan berupa trust, networking social, pertukaran (resiprocity) dan aturan bersama-sama dengan modal lainnya akan sangat mendukung susksesnya sebuah program (Fukuyama, 2007). Menurut Syahyuti (2008) modal sosial sangat berbeda dengan modal finansial, dimana dengan semakin sering modal sosial digunakan akan semakin kuat sebaliknya modal finansial mungkin akan semakin habis.

\section{- Manajemen massa yang baik}

Manajemen massa merupakan bagian penting dalam sebuah pergerakan. Demikian pula gerakan rehabilitasi lahan seperti halnya program penghijauan atau program pengembangan hutan rakyat yang melibatkan pesantren. Apabila massa dapat dikelola dengan baik, semua pelaku berada dalam satu tujuan dan kepentingan yang sama maka program akan lebih mudah dilaksanakan.

Kemampuan manajemen massa ini terkait dengan keunggulan kharismatik kyai. Selain kemampuan pimpinan dan pengurus pesantren yang mampu mengelola massa dengan baik, jumlah santri dan pengikut pesantren seperti majelis taklim juga merupakan kekuatan yang dimiliki pesantren untuk menjalankan program dengan baik.

\section{B. KESIMPULAN DAN SARAN}

\section{A. Kesimpulan}

1. Sebagai lembaga kemasyarakatan pesantren memiliki keunggulan komparatif pada aspek SDM, demografi, ekonomi dan sosial yang tidak dimiliki oleh lembaga lain. Aspek tersebut menjadi ciri pesantren dan menjadi kekuatan yang menonjol, terutama ketika ada kebutuhan massa dalam jumlah besar pada kegiatan RHL untuk menanam dan memelihara lingkungan yang dapat dipenuhi oleh pesantren.

2. Faktor keunggulan yang dimiliki pesantren diantaranya adalah : letak pesantren berada langsung ditengah masyarakat dengan lokasi di semua tempat (daerah pantai, pegunungan, pertanian dan tepi sungai), jumlah lembaga pesantren banyak dengan organisasi yang jelas, memiliki Kyai yang karismatik dengan jumlah santri dan mustame yang banyak. 


\section{B. Saran}

Peran pesantren yang menonjol saat ini masih terletak pada kegiatan kehutanan di sektor hulu. Untuk terlibat dalam kegiatan RHL, pesantren masih memiliki kelemahan diantaranya adalah dalam hal pengembangan ilmu pengetahuan dan teknologi manajemen dan bisnis dibidang kehutanan. Kelemahan tersebut bukan menjadi hambatan tetapi sebagai pendorong pesantren untuk lebih meningkatkan sistem pengajarannya. Hal ini dapat dilakukan dengan cara bekerjasama dengan lembaga-lembaga pendidikan dan teknis yang terkait dengan ilmu kehutanan.

\section{DAFTAR PUSTAKA}

Anonim. 2005. Pontren Berperan Strategis Menanggulangi Lahan Kritis. Umumnya Berlokasi di Pedesaan Dekat dengan Hutan. Http:/ / www.pikiran-rakyat.com/cetak/ 2005/0305/22/1101.htm. Diakses tanggal 6 Juli 2008.

Anonim. 2007. Pedoman Teknis Gerakan Nasional Rehabilitasi Hutan dan Lahan (GNRHL/Gerhan). Departemen Kehutanan. Jakarta.

Anonim. 2010. Perbedaan Keunggulan Kompetitif dengan Keunggulan Komparatif. http:/www.hidayaters.wordpress.com/.../perbedaan-keunggulan-kompetitifdengan-keunggulan-komparatif/. Diakses tanggal 6 Mei 2010.

Awang, S.A., E. B. Wiyono dan S. Sadiyo. 2007. Unit Manajemen Hutan Rakyat: Proses Konstruksi Pengetahuan Lokal. Banyumili Art Network, Sleman.

Diniyati, D., Fauziyah, E., Achmad, B. 2008. Kajian Kontribusi Pondok Pesantren Pada Kegiatan Rehabilitasi Hutan dan Lahan. Prosiding. Pembangunan Hutan Rakyat Melalui Optimalisasi Hasil dan Diversivikasi Produk Tanaman Multiguna dalam Menunjang Kemandirian Ekonomi dan Energi. Seminar Hasil-hasil Penelitian Balai Penelitian Kehutanan Ciamis. Pusat Penelitian dan Pengembangan Hutan Tanaman, Bogor.

Fukuyama, F. 2007. The Great Disruption. Hakikat Manusia Dan Rekonstitusi Tatanan Sosial. Penerbit Qalam, Jakarta.

Hermawan. 2007. Pesantren dan Krisis Lingkungan. http://www agama dan ekologi.blogspot.com/2007/04/pesantren-dan-krisis-lingkungan.html. Diakses tanggal 25 oktober 2007.

Jones, S. 1991. The Javanese Pesantren: between elite and peasantry, in Reshaping Local Worlds: formal education and cultural change in rural South-East Asia, New Haven, Conn: Yale Center for International and Area Studies.

Maarif, NH. 2007. Menanti Kiprah Riil Pesantren. http://www.mambaussholihin. com/ $\underline{\text { artikel/index.php?category }=\text { tarbiyah\&nomor }=15}$. Diakses tanggal 25 November 2007

Musaddad, T.D. 2007. Pembangunan Pedesaan Mandiri. Berbasis Amal Shaleh Sosial Berwawasan Lingkungan. Humaniora. Bandung. 
Nasution, M. 1999. Dephutbun dan MUI Jalin Kerjasama: Pontren Belum Pernah Disentuh. Majalah Kehutanan Indonesia (MKI), Edisi I/XIII/1999 2000, Jakarta.

O'Hanlon, M.G. 2006. Pesantren dan Dunia Pemikiran Santri: Problematika Metodologi Penelitian yang Dihadapi Orang Asing. Program ACICIS Angkatan XXI, 2005-2006. Fakultas Ilmu Sosial dan Ilmu Politik, Universitas Muhammadiyah Malang, Malang.

Qamarudin. 2005. Pendidikan Lingkungan Berbasis Pontren. http://www.pikiranrakyat.com/cetak/2005/0305/22/1101.htm. Diakses tanggal 25 September 2007.

Saptana. 2008. Keunggulan Komparatif-Kompetitif dan Strategi Kemitraan. http:// www. Pse.litbang.deptan.go.id/ind.pdf.file. Diakses tanggal 19 Januari 2008.

Soekanto, S. 2003. Sosiologi Suatu Pengantar. PT. RajaGrafindo Persada, Jakarta.

Suyuti, A. 2008. Pengertian Pondok Pesantren. http///www.damandiri.or.id / file/ ahmadsuyutiunairbab2.pdf. Diakses pada tanggal 24 Juli 2008.

Syahyuti.2008.SocialCapital.http://www.geocities.com/syahyuti/social_capital.pdf. Diakses tanggal 4 Desember 2008. 